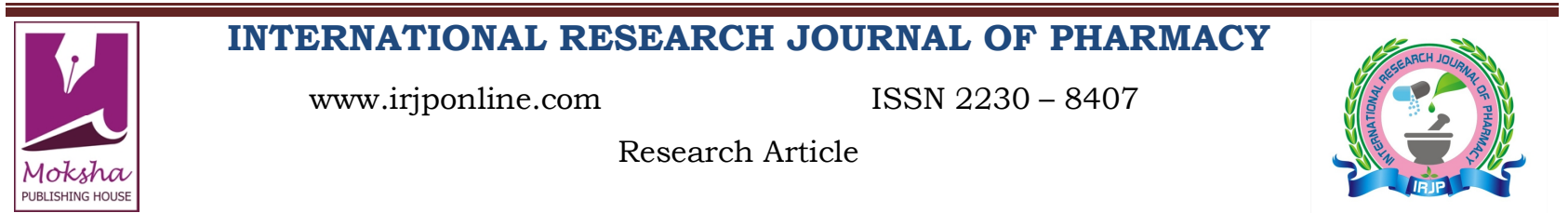

\section{ROLE OF HEMATOLOGICAL PARAMETERS IN DIAGNOSIS AND PROGNOSIS OF GASTRIC CARCINOMA IN KASHMIR, INDIA}

Rabia Farooq ${ }^{1}$, Arif Akbar Bhat ${ }^{1}$, Hilal Ahmad Wani ${ }^{1}$, Hamid Bashir ${ }^{1}$, Nisar Ahmad Naikoo ${ }^{2}$, Shajrul Amin ${ }^{3}$, Bashir Ahmad Ganai ${ }^{4}$, Sabhiya Majid ${ }^{5 *}$

${ }^{1}$ Research Scholar, Department of Biochemistry, Government Medical College, Srinagar, India

${ }^{2}$ Lecturer Department of Biochemistry, Government Medical College, Srinagar, India

${ }^{3}$ Senior Assistant Professor, Department of Biochemistry, University of Kashmir, India

${ }^{4}$ Professor, Department of Biochemistry, University of Kashmir, India

${ }^{5}$ Professor and Head, Department of Biochemistry, Government Medical College, Srinagar, India

*Corresponding Author Email: rabiajan4uuu@gmail.com

Article Received on: 10/06/13 Revised on: 01/07/13 Approved for publication: 11/08/13

DOI: $10.7897 / 2230-8407.04824$

IRJP is an official publication of Moksha Publishing House. Website: www.mokshaph.com

(C) All rights reserved.

\section{ABSTRACT}

Gastric cancer is the second leading cause of death in the world. More than two-thirds of the patients are diagnosed at an advanced stage. Metastatic gastric cancer has poor prognosis with a median 5 years-survival rate of $7 \%$. Hematological parameters including leukocyte count, platelet count and their ratios have been used as prognostic indicators in several tumor types. The aim of the study was to examine an association of the difference in haematological parameters between gastric cancer patients and normal controls of Kashmir valley. We enrolled 210 subjects of which 110 were newly diagnosed gastric cancer cases and 100 were healthy controls. Participants were recruited from hospitals, clinics and radiology department of Shri Maharaja Hari Singh (SMHS) hospital Srinagar, India from May 2011 to Apr 2012. After informed consent, all patients were interviewed and examined and demographic and clinical information was collected. Blood samples were drawn for examination of hematological measures and for measurement of carcino embryonic antigen (CEA). We found the hematological parameters like: $\mathrm{Hb}(10 \pm 2, \mathrm{P}=0.004), \mathrm{MCV}(84.25 \pm 5, \mathrm{p}=0.01)$, Granulocyte $\%(70.04 \pm 10.63, \mathrm{p}=0.001), \mathrm{Lymphocyte} \%(26.12 \pm$ $10.7, \mathrm{p}<0.0001)$, RDW $(48 \pm 10, \mathrm{p}=0.004)$ in gastric cancer patients and these were found to be highly decreased as compared to normal healthy controls where hematological parameters was in normal range. Our study was statistically significant $(\mathrm{p}<0.005)$. The study suggests that the hematological parameters like HB, MCV, Granulocyte \%, Lymphocyte \% and RDW are decreased in gastric cancer patients and acts as an early marker in the prognosis and diagnosis of gastric cancer.

Keywords: Gastric cancer, Hematological parameters, CEA, SMHS.

\section{INTRODUCTION}

Gastric cancer being the second most common cancer, occurring worldwide year in the world ${ }^{1,2}$. Early disease causes minimal, nonspecific or no symptoms. Therefore prognosis for gastric cancer patients remains poor as most patients are diagnosed in advanced stages. There are definite ethnic and geographic trends in gastric cancer incidence; being high in Japan, Chile, Costa Rica, Colombia, China, Portugal, Iceland, Finland and Scotland ${ }^{3}$, lower in US, UK, Canada, Greece, New Zealand, Sweden and Honduras ${ }^{4}$. Twothird of the cases occurs in the developing countries ${ }^{5}$. Early disease may be asymptomatic or may cause minimal, nonspecific symptoms. Therefore, prognosis of gastric cancer patients remains poor as most of the patients are diagnosed at advanced stages. Studies have shown incidence rates in men are twofold higher than those in the women. The state of Kashmir, India has an increased gastric malignancy with the frequency of 50-60 cases per 100,000 persons and $63 \%$ of these cases occur in southern districts of Kashmir ${ }^{6}$. The likely reasons for higher frequency of gastric cancer are high dietary intake of meat, salt, barbeques, grilled and starchy food, smoked food and pickled foods ${ }^{7}$. The role of immune system on disease progression has been investigated previously and the prognostic importance of some hematological parameters including leukocyte and platelet counts, mean platelet volume (MPV) have been shown in various malignancies ${ }^{9-13}$. In addition, the neutrophillymphocyte ratio (NLR) has been reported as a simple marker of systemic inflammatory response in cancer patients ${ }^{14,15}$. Similarly, preoperative thrombocyte to lymphocyte ratio (TLR) has been suggested as a significant factor that predicts survival in patients with pancreatic cancer ${ }^{16}$. Both NLR and thrombocytosis have been reported as prognostic factors in patients with gastric cancer ${ }^{19,20}$. TLR and lymphocyte counts were found as prognostic factor that predicts advanced gastric cancer $^{21}$. The evaluation of hematological parameters is easy and cost-effective in determination of prognosis and tumor response to therapy. In this study we investigated whether lymphocyte, neutrophil and platelet counts, TLR and NLR had prognostic importance in predicting the survival in metastatic gastric cancer patients.

\section{MATERIALS AND METHODS}

Subjects and Recruitment Process

This study was conducted in the Department of Biochemistry, Government Medical College, Srinagar, India from May 2011 to April 2012. We enrolled 210 subjects of which 110 were newly diagnosed gastric cancers cases and 100 were healthy age-sex matched controls. All patients were referred either from outpatient clinics or were admitted to the Shri Maharaja Hari Singh Hospital. All participants underwent a complete blood count (CBC) and measurement of CEA. The study was approved by the ethical committee of the Department of Biochemistry, Government Medical College (GMC) Srinagar, India. Individuals who fulfill inclusion criteria for this disease and gave consent to participate in the study were recruited as controls. Patients and normal were age and sex matched.

Data of the patients was obtained from medical records. 


\section{Exclusion Criteria}

Patients with chronic disease such as chronic renal failure, patients who had recently received blood transfusion and those with active infection were excluded from the study.

\section{Blood Sample Collection}

About 5-6 ml of venous blood was collected, $3 \mathrm{ml}$ blood was taken in EDTA vials and remaining $3 \mathrm{ml}$ was centrifuged to separate serum from the cells as soon as the clot was formed.

\section{Measurement of Hematological Parameters}

The $3 \mathrm{ml}$ peripheral venous blood was taken in sterilized EDTA vials. Blood samples were processed manually for various haematological indices mainly hemoglobin $(\mathrm{Hb})$, total erythrocyte counts (TEC), total leukocyte count (TLC), mean corpuscular value (MCV), mean corpuscular hemoglobin $(\mathrm{MCH})$, mean corpuscular hemoglobin concentration (MCHC), Red cell width distribution (RDW). The $\mathrm{CBC}$ and haemogram were assayed in Sysmex (Italy) haemocytometer analyzer. The Erythrocyte sedimentation rate (ESR) was determined by Wintrobe's method. The $\mathrm{Hb} \%$, $\mathrm{RBC} \%$ and Color Index were determined by these formulae (Godkar et al, 2006).

$$
\begin{gathered}
\mathrm{Hb} \%=100 * \mathrm{Hb} \text { value } / 14.5 \\
\mathrm{RBC} \%=100 * \mathrm{RBC} \text { Count } / 5.0 \\
\text { Color Index }=\mathrm{Hb} \% / \mathrm{RBC} \%
\end{gathered}
$$

\section{Measurement of Cancer Marker}

Serum aliquots were stored at $4^{\circ} \mathrm{C}$. The samples were allowed to thaw prior to assay, mixed thoroughly. Hemolysed and lipemic samples were rejected. CEA analysis was carried out by electro chemiluminescence Immuno assay method using fully automatic analyzer ECLIA 2010 (Roche Diagnostic Germany).

\section{Statistical Analysis}

Data were recorded and analyzed by SPSS 16.0. The results were expressed as mean \pm standard deviation (SD). Differences in variables were analyzed by t-test. The differences were considered to be significant at $\mathrm{p}<0.05$.

\section{RESULTS}

210 subjects participated in the research. Among which $64 \%$ were males and $36 \%$ were females, in the age group between 25-60 years. Reviewed hospital records were taken from were taken from Department of Biochemistry, Government Medical College, Srinagar, India. Median + Standard deviation values of $\mathrm{Hb}, \mathrm{RBC}, \mathrm{WBC}, \mathrm{MCV}$, RDW, Hct, Lym $\%, \mathrm{Hb} \%, \mathrm{RBC} \%$ with respect to $\mathrm{CEA}$ analysis were assessed and after assessment we found the hematological parameters like $\mathrm{Hb}$ like: $\mathrm{Hb}(10 \pm 2, \mathrm{P}=0.004), \mathrm{MCV}(84.25$ $\pm 5, \mathrm{p}=<0.005)$, Granulocyte $\%(70.04 \pm 10.63, \mathrm{p}=<$ $0.0001)$, Lymphocyte \% $(26.12 \pm 10.7, \mathrm{p}<0.0001)$, RDW $(48 \pm 10, \mathrm{p}=0.004)$ in gastric cancer patients were highly decreased as compared to normal healthy controls where haematological parameters was in normal range (table 1). Other parameters like RBC, WBC, Hct, Lym \%, Hb \%, RBC $\%$ were also found to be also significantly decreased in the gastric cancer patients. $\mathrm{p}<0.05$ is statistically significant and have association in the gastric cancer disease. Also, we interviewed all the patients and controls by providing them questionnaire and information was obtained from them.

Table 1: Haematological Parameters in Gastric Cancer Patients and Healthy Controls

\begin{tabular}{|c|c|c|c|}
\hline Hematological Parameters & Gastric cancer patients $(\mathbf{n}=\mathbf{1 1 0})$ Mean \pm SD & Normals $(\mathbf{n}=\mathbf{1 0 0})$ Mean \pm SD & P value \\
\hline $\mathrm{Hb}(\mathrm{g} / \mathrm{dl})$ & $10.83 \pm 2$ & $14.72 \pm 1.2$ & 0.004 \\
\hline $\mathrm{MCV}$ & $84.25 \pm 5$ & $85 \pm 8.5$ & 0.011 \\
\hline Granulocyte \% & $70.04 \pm 10.63$ & $49.60 \pm 26.49$ & $<0.0001$ \\
\hline Lymphocyte \% & $26.12 \pm 10.76$ & $39.55 \pm 20.93$ & $<0.0001$ \\
\hline $\mathrm{RDW}$ & $48 \pm 10$ & $28 \pm 5$ & 0.004 \\
\hline $\mathrm{RBC}\left(10^{6} / \mu \mathrm{l}\right)$ & $4.2 \pm 0.5$ & $5.1 \pm 1.99$ & 0.0021 \\
\hline $\mathrm{HCT}(\%)$ & $37 \pm 2$ & $42 \pm 2$ & 0.004 \\
\hline WBC $\left(10^{3} / \mu \mathrm{l}\right)$ & $5.18 \pm 2.27$ & $6.60 \pm 1.08$ & 0.0002 \\
\hline $\mathrm{RBC}(\%)$ & $79.91 \pm 11.35$ & $80.06 \pm 12.14$ & 0.0116 \\
\hline PLT & $217.1 \pm 91.60$ & $187.5 \pm 25.44$ & 0.002 \\
\hline $\mathrm{HB} \%$ & $72.40 \pm 11.5$ & $75.04 \pm 8.67$ & 0.006 \\
\hline
\end{tabular}

Comparison of haematological parameters in gastric cancer patients and normal; The results are reported in these groups as mean \pm SD, which are statistically tested by Two- point ANOVA

Table 2: CEA Parameters in Gastric Cancer Patients and Healthy Controls

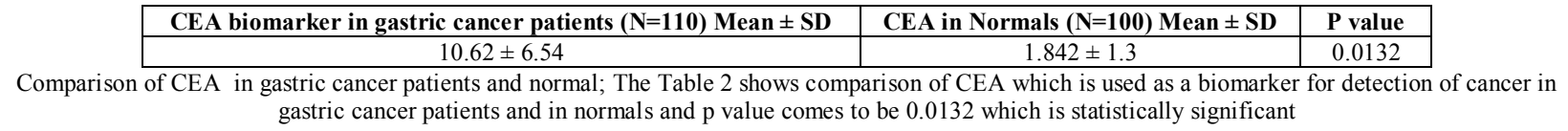

Hence the decrease in hematological parameters and CEA levels are highly associated with increase in risk of developing cancer. So, assessment of these parameters would be highly beneficial for early diagnosis and thus early treatment of this disease.

\section{DISCUSSION}

Gastric carcinoma is one of the most common malignancies in the world, yet little is known about its molecular process of development and progression.Various treatments have failed to improve the survival rate in gastric cancer. Therefore, prevention and early detection of the tumor are essential to reduce cancer deaths resulting from gastric cancer. The prevalence of gastric cancer is constantly increasing, especially among men. In the present study predominant population with gastric cancers are observed in males. Cancer are frequently associated with erythrocyte abnormalities ${ }^{19}$. Recently the role of immune system on cancer progression was examined and leukocytes have been proposed as a diagnostic and prognostic factor in variety of cancers ${ }^{10}$. Previously, it was reported that pretreatment lymphocyte count had been independent prognostic factor in lung, colorectal and gastric cancer ${ }^{26-29}$. Low lymphocyte counts $(<$ $1500 / \mathrm{mm}$ ) indicate cell-mediated immunodeficiency which 
was common feature in cancer physiology, but also that is relevant prognostic role for survival ${ }^{28}$. The cancer related lymphopenia occur in advanced stage cancers such as small cell lung cancer, colorectal cancer and renal cell cancer ${ }^{28}$. Bruckner et al. suggested that, pretreatment lymphocyte counts of $1500 / \mathrm{mm}$ and neutrophil counts of $<6000 / \mathrm{mm}$ were independent prognostic factors for survival in the metastatic gastric cancer. Cancer can cause certain forms of anemia on the one hand or hyper proliferation of immature progenitors on the other hand. The anemia is usually macrocytic hypochromic and or normocytic anemia and anemia will be of moderate severity ${ }^{18}$. The anemia in cancer patients has been ascribed to a physiological compensation for the diminished need of tissues for oxygen. The low plasma erythropoietin levels found in cancer is in accord with this hypothesis. In our study we found hematological parameters of gastric cancer patients And compared them with normal and observed that $\mathrm{CBC}$ them with normal and we observed that $\mathrm{CBC}$ parameters levels decrease in cases like $\mathrm{RBC}, \mathrm{Hb}, \mathrm{MCH}$, PLT Levels. and $\mathrm{p}$ value was found to be less than 0.05 hence study is found to be (statistically significant).

\section{CONCLUSION}

Gastric cancer has a significant influence on erythropoiesis. In view of decreased haematological parameters like $\mathrm{Hb}$, $\mathrm{RBC}, \mathrm{MCV}, \mathrm{HCT}, \mathrm{RBC} \%$ and RDW in gastric cancer, it suggests that abnormal levels of these parameters might substantially influence the size variability of circulating RBC's, predisposes patient to Normocytic anemia. There might be some limitation with this study like, missing data, non-funding, less sample size, hospital based data etc. These changes need to be further should be investigated and corrected. Their presence could steer towards gastric cancer allowing its early management and thus likelihood of the disease may be decreased and also decrease in disease recurrence especially in Kashmir valley which is cancer prone area.

\section{ACKNOWLEDGEMENT}

We acknowledge both technical staff of Department of Biochemistry, SMHS Hospital Srinagar, India for technical assistance in this research. Also, we are thankful to Mr Haamid who helped us to make this original article best for publication. Besides special thanks to my friend Dr Zaffer who really encouraged me for my research work.

Abbreviations: Haemoglobin (HB), Mean corpuscular volume (MCV), RDW (red cell distribution width)

\section{REFERENCES}

1. Parkin DM, Pisani P, Ferlay J. Estimates of the worldwide incidence of 25 major cancers. Int. J. Cancer 1990; 80: 827-41. http://dx.doi.org/ 10.1002/(SICI)1097-0215(19990315)80:6<827::AID-IJC6>3.0.CO;2-P

2. Chan $\mathrm{AOO}$ and Rashid $\mathrm{A}$. $\mathrm{CpG}$ island methylation in precursors of gastrointestinal malignancies. Curr. Mol. Med 2006; 6: 401-408. http:/ /dx.doi.org/10.2174/156652406777435417 PMid:16900663

3. $\mathrm{Wu} \mathrm{CW}$, Chi CW and Lin W. Gastric cancer; prognostic and diagnostic advances. Expert Rev Mol Med 2002; 4(6): 1-12. http://dx.doi.org/ 10.1017/S1462399402004337 PMid: 14987390

4. Dunham LJ and Bailer C.World maps of cancer mortality rates and frequency ratio. J. Natl .Cancer Inst 1968; 41: 155-203. PMid:5662021

5. Devesa SS and Silverman DT. Cancer incidence and mortality: trends in the United States 1934-74. Natl. Cancer Inst 1978; 60: 545-571.

6. Khuroo MS, Zargar SA, Mahajan R and Banday MA. High incidence of oesophageal and gastric cancer in Kashmir, India in a population with special personal and dietary habits. Gut; 1: 11-5.

7. Liu C, Russel RM. Nutrition and gastric cancer risk; an update. Nutr. Rev 2008; 5: 237-49. http://dx.doi.org/10.1111/j.1753-4887.2008. 00029.x PMid: 18454810

8. Teramukai S, Kitano T, Kishida Y, Kawahara M, Kubota K, Komuta K, Minato K, Mio T, Fujita Y, Yonei T, Nakano K, Tsuboi M, Shibata K,
Furuse K, Fukushima M. Pre treatment neutrophil count as an independent prognostic factor in advanced non small cell lung cancer: an analysis of Japan Multinational Trial Organisation LC00-03. Eur J Cancer 2009; 45: 1950-8. http://dx.doi.org/10.1016/j.ejca.2009.01.023 PMid: 19231158

9. Yamanaka $\mathrm{T}$, Matsumoto $\mathrm{S}$, Teramukai S, Ishiwata R, Nagai $\mathrm{Y}$, Fukushima M. The baseline ratio of neutrophils to lymphocytes with patient prognosis in advanced gastric cancer. Oncology 2007; 73: 21520. http://dx.doi.org/10.1159/000127412 PMid:18424885

10. Smith RA, Ghaneh P, Sutton R, Raraty M, Campbell F, Neoptolemos JP. Prognosis of resected ampullary adenocarcinoma by preoperative serum CA19-9 levels and platelet-lymphocyte ratio. J Gastrointest Surg 2008; 12: 1422-8. http://dx.doi.org/10.1007/s11605-008-0554-3 PMid: 18543046

11. Shimada H, Oohira G, Okazumi S, Matsubara H, Nabeya Y, Hayashi H, Takeda A, Gunji Y, Ochiai T. Thrombocytosis associated with poor prognosis in patients with esophageal carcinoma. J Am Coll Surg 2004; 198: 737-41. http://dx.doi.org/10.1016/j.jamcollsurg.2004.01.022 PMid: 15110807

12. Rodriguez GC, Clarke Pearson DL, Soper JT, Berchuck A, Synan I, Dodge RK. The negative prognostic implications of thrombocytosis in women with stage IB cervical cancer. Obstet Gynecl 1994; 83: 445-8. PMid:8127540

13. Zahorec R. Ratio of neutrophil to lymphocyte counts-rapid and simple parameter of systemic inflammation and stress in critically ill. Bratisl Lek Listy 2001; 102: 5-14.

14. Cho H, Hur HW, Kim SW, Kim SH, Kim JH, Kim YT, Lee K. Treatment neutrophil to lymphocyte ratio is elevated in epithelial ovarian cancer and predicts survival after treatment. Cancer Immunol Immunother 2009; 58: 15-23. http://dx.doi.org/10.1007/s00262-0080516-3 PMid: 18414853

15. Smith RA, Bosonnet L, Raraty M, Sutton R, Neoptolemos JP, Campbell F, Ghaneh P. Preoperative platelet-lymphocyte ratio is an independent significant prognostic marker in resected pancreatic ductal adenocarcinoma. Am J Surg 2009; 197: 466-72. http://dx.doi.org /10.1016/j.amjsurg.2007.12.057 PMid:18639229

16. Hong WS, Hong SI, Kim CM, Kang YK, Song JK, Lee MS, Lee JO, Kang TW. Differential depression of lymphocyte subsets according to stage in stomach cancer. Jpn J Clin Oncol 1991; 21: 87-93. PMid:2067132

17. Hong WS, Min YI, Son YS, Hong SI. Peripheral blood lymphocyte subsets in patients with stomach cancer. J Korean Med Sci 1995; 10: 164-8. PMid:8527041 PMCid:PMC3054115

18. Ikeda M, Furukawa H, Imamura H, Shimizu J, Ishida H, Masutani S, Tatsuta M, Satomi T. Poor prognosis associated with thrombocytosis in patients with gastric cancer. Ann Surg Oncol 2002; 9: 287-91. http://dx.doi.org/10.1007/BF02573067 PMid:11923136

19. Gwak MS, Choi SJ, Kim JA, Ko JS, Kim TH, Lee SM, Park JA, Kim $\mathrm{MH}$. Effects of gender on white blood cell populations and neutrophillymphocyte ratio following gastrectomy in patients with stomach cancer. J Korean Med Sci 2007; 22: 104-8. http://dx.doi.org/10.3346 /jkms.2007.22.S.S104 PMCid:PMC2694399

20. Zurabkhet S, Alexander SS, Remigvamichava, Klarakhet S. Hematological parameters in patients with Helicobacter pylori associated gastric cancer. Annlas of biomedical research and education. $2002 ; 2(3): 179-275$.

21. Aliustaoglu M, Bilici A, Ustaalioglu BB, Konya V, Gucun M, Seker M, Gumus M. The effect of peripheral blood values on prognosis of patients with locally advanced gastric cancer before treatment. Med Oncol 2010; 27:1060-5.http://dx.doi.org/10.1007/s12032-009-9335-4 PMid:1984 7679

22. Cho H, Hur HW, Kim SW, Kim SH, Kim JH, Kim YT, Lee K. Pretreatment neutrophil to lymphocyte ratio is elevated in epithelial ovarian cancer and predicts survival after treatment. Cancer Immunol Immunother 2009; 58: 15-23. http://dx.doi.org/10.1007/s00262-0080516-3 PMid: 18414853

23. Zhang L, Conejo Garcia JR, Katsaros D, Gimotty PA, Massobrio M, Regnani G, Makrigiannakis A, Gray H, Schlienger K, Liebman MN, Rubin SC, Coukos G. Intra tumoral T cells, recurrence and survival in epithelial ovarian cancer. N Engl J Med 2003; 348: 203-13. http://dx.doi.org/10.1056/NEJMoa020177 PMid:12529460

24. Fogar P, Sperti C, Basso D, Sanzari MC, Greco E, Davoli C, Navaglia F, Zambon CF, Pasquali C, Venza E, Pedrazzoli S, Plebani M. Decreased total lymphocyte counts in pancreatic cancer: an index of adverse outcome. Pancreas 2006; 32: 22-8. http://dx.doi.org/10.1097/ 01.mpa.0000188305.90290.50 PMid: 16340740

25. Fumagalli LA, Vinke J, Hoff W, Ypma E, Brivio F, Nespoli A. Lymphocyte counts independently predict overall survival in advanced cancer patients: a biomarker for IL-2 immunotherapy. J Immunother 2003; 26: 394-402. http://dx.doi.org/10.1097/00002371-20030900000002 PMid: 12973028 
26. Blake Mortimer JS, Sephton SE, Carlson RW, Stites D, Spiegel D. Cytotoxic $\mathrm{T}$ lymphocyte count and survival time in women with metastatic breast cancer. Breast J 2004; 10: 195. http://dx.doi.org/ 10.1111/j.1075-122X.2004.21290.x PMid:15125744

27. Fumagalli LA, Vinke J, Hoff W, Ypma E, Brivio F, Nespoli A. Lymphocyte counts independently predict overall survival in advanced cancer patients: a biomarker for IL-2 immunotherapy. J Immunother 2003; 26: 394-402. http://dx.doi.org/10.1097/00002371-20030900000002 PMid: 12973028

28. Bruckner HW, Lavin PT, Plaxe SC, Storch JA, Livstone EM. Absolute granulocyte, lymphocyte and monocyte counts. Useful determinants of prognosis for patients with metastatic Cancer of the stomach. JAMA 1982; 247: 1004-6. http://dx.doi.org/10.1001/jama.247.7.1004 http://dx. doi.org/10.1001/jama.1982.03320320040027 PMid:7035703

Cite this article as:

RabiaFarooq, Arif Akbar Bhat, Hilal Ahmad Wani, Nisar Ahmad Naikoo, Hamid Bashir, Shajrul Amin, Bashir Ahmad Ganaie, Sabhiya Majid. Role of hematological parameters in diagnosis and prognosis of gastric carcinoma in Kashmir, India. Int. Res. J. Pharm. 2013; 4(8):134-137 http://dx.doi.org/ $\underline{10.7897 / 2230-8407.04824}$

Source of support: Nil, Conflict of interest: None Declared 